\title{
Analysis of the influence of different types of cement on the resistance to attack by sulfates
}

\section{Análise da influência de diferentes tipos de cimento na resistência ao ataque por sulfatos}

\author{
Daniele Neida Schiavini ${ }^{1}$; Wellington Mazer $^{2}$; Elizamary Otto Ferreira ${ }^{3}$; \\ Juliana M. McCartney da Fonseca ${ }^{4}$
}

\begin{abstract}
The diversity of the types of cement manufactured, driven by the extensive use of additions, has given cementitious composites properties that can directly interfere in the durability and useful life of concrete. Considering the interaction of sulfate ions with cement hydration products, in order to understand it becomes essential for the proper choice of materials in order to protect the structures from this aggressor agent. In order to verify the influence of the choice of cement type on the resistance to attack by sulfates, this article analyzes the compressive strength; sulfate content, electron microscopy and energy dispersive spectroscopy of mortars made with cements CP II-F-32, CP IV-32 and CP V-ARI submitted to calcium, sodium and magnesium sulfate solutions for 4 months. The specimens exposed to calcium and sodium sulfate solutions showed increased compressive strength at early ages due to the formation of ettringite in the pores. On the other hand, CP II-F-32 cement showed the greatest deterioration due to magnesium sulfate attack.
\end{abstract}

Keywords: Ettringite. Sulfate attack. Microstructure. Cements. Durability.

\section{Resumo}

A diversidade dos tipos de cimento fabricados, impulsionada pelo uso extensivo de adições, tem conferido aos compósitos cimentícios propriedades que podem interferir diretamente na durabilidade e vida útil dos concretos. Considerando a interação dos íons sulfato com os produtos da hidratação do cimento, de forma a compreendê-la torna-se imprescindível para a escolha adequada dos materiais a fim de proteger as estruturas deste agente agressor. Com o objetivo de verificar a influência da escolha do tipo de cimento na resistência ao ataque por sulfatos, este artigo analisa a resistência à compressão; teor de sulfato, microscopia eletrônica e espectroscopia de energia dispersiva de argamassas confeccionadas com os cimentos CP II-F-32, CP IV-32 e CP V-ARI submetidas a soluções de sulfato de cálcio, sódio e magnésio por 4 meses. Os corpos de prova expostos às soluções de sulfato de cálcio e sódio apresentaram aumento da resistência à compressão nas idades iniciais devido à formação de etringita nos poros. Por outro lado, o cimento CP II-F-32 apresentou as maiores deteriorações devido ao ataque do sulfato de magnésio.

Palavras-chave: Etringita. Ataque por sulfatos. Microestrutura. Cimentos. Durabilidade.

\footnotetext{
${ }^{1}$ Civil Engineering student, DACOC/UTFPR, UTFPR, Curitiba, PR, Brazil. E-mail: danieleschiavini@gmail.com

2 Prof. Dr., Academic Department of Civil Construction, UTFPR, Curitiba, PR, Brazil. E-mail: wmazer@utfpr.edu.br

${ }^{3}$ Master student, DACOC/UTFPR, UTFPR, Curitiba, PR, Brazil. E-mail: elizamaryotto@ gmail.com

${ }^{4}$ Master student, DACOC/UTFPR, UTFPR, Curitiba, PR, Brazil. E-mail mccartney.juliana@gmail.com
} 


\section{Introduction}

Throughout its useful life, concrete must withstand the conditions of design and aggression of the environment in which it will be inserted. Therefore, the correct specification of materials for execution is a premise for increasing the durability of structures, resisting in a favorable way to deterioration processes (HOPE FILHO et al., 2015).

The attack of sulfates in the concrete comprises a series of chemical reactions between the sulfate ions, coming from external sources or released internally after heating, with the hydrated calcium aluminate salts present in the cement paste, resulting in the formation of secondary ettringite, causing the increase in volume inside the concrete, generating tensile efforts that culminate in the formation of micro cracks (CEFIS; COMI, 2017). Another aspect that influences, according to Guo et al. (2021) is the drywet cycle and the period of this cycle. Wang et al. (2020) observed that the duration of the wet-dry period also influences the deterioration of concrete.

Several studies have been carried out in order to better understand how the attack of sulfates in concrete occurs, the consequences of this attack and ways to try to avoid or reduce these reactions (NAJIMI; POURKHORSHIDI, 2011; ZHANG et al., 2013; ZHANG et al., 2020). In this context, this article aims to understand the mortar interaction of CP II F-32, CP IV-32 and CP V-ARI cement under attack by sodium, magnesium and calcium sulfates, through an experimental study that evaluated compressive strength, sulfate content, electron microscopy (SEM) and energy dispersive spectroscopy (EDS), before and after sulfate attacks.

\section{Calcium sulfate attack mechanism}

Calcium sulfate $\left(\mathrm{CaSO}_{4}\right)$ is considered the least aggressive of the types of sulfates due to the low solubility of this salt. There are two aspects to explain the mechanism of attack of concrete structures by $\mathrm{CaSO}_{4}$ : the first one says that due to the low solubility, there is little concentration in the water contained in the soil, limiting the ability to penetrate and attack concrete structures; the second argues that once $\mathrm{CaSO}_{4}$ penetrates the concrete, its solubility increases due to the high alkalinity present in the concrete pores. After solubilization and with a greater number of free sulfate ions, $\mathrm{CaSO}_{4}$ can become a potentially aggressive agent for hydrated cement paste (SKALNY; MARCHAND; ODLER, 2003).
In equation (1), it is indicated how calcium sulfate reacts with hydrated calcium aluminate to form ettringite (PIASTA; MARCZEWSKA; JAWORSKA, 2014):

$$
\begin{gathered}
3\left(\mathrm{CaSO}_{2} \cdot 2 \mathrm{H}_{2} \mathrm{O}\right)+4 \mathrm{CaO} \cdot \mathrm{Al}_{2} \mathrm{O}_{3} \cdot 19 \mathrm{H}_{2} \mathrm{O}+17 \mathrm{H}_{2} \mathrm{O} \\
\rightarrow 3 \mathrm{CaO} \cdot \mathrm{Al}_{2} \mathrm{O}_{3} \cdot 3 \mathrm{CaSO}_{4} \cdot 32 \mathrm{H}_{2} \mathrm{O}
\end{gathered}
$$

The initial manifestation of the interaction between Portland cement and calcium sulfate solution is an increase in strength, as the pores of the cement paste become filled with the newly formed ettringite. However, if the formation of ettringite continues to occur over time, exceeding the spatial capacity of the pore, an expansive tension can arise that can lead to the expansion and cracking of the material (SKALNY; MARCHAND; ODLER, 2003).

\section{Sodium sulfate attack mechanism}

The first form of attack involves $\mathrm{Na} 2 \mathrm{SO} 4$ reacting with $\mathrm{CH}$ (portlandite) to form gypsum, which precipitates, as indicated in equation (2). Another way is the reaction of sodium sulfate with the hydrated calcium aluminate phases, also with formation of ettringite, indicated in equation (3) and equation (4) (PIASTA; MARCZEWSKA; JAWORSKA, 2014):

$$
\begin{aligned}
& \mathrm{Ca}(\mathrm{OH})_{2}+\mathrm{Na}_{2} \mathrm{SO}_{4} \cdot \mathrm{H}_{2} \mathrm{O} \\
& \rightarrow \mathrm{CaSO}_{4} \cdot \mathrm{H}_{2} \mathrm{O} \downarrow+2 \mathrm{NaOH}, \\
& 2 \mathrm{Na}_{2} \mathrm{SO}_{4}+3 \mathrm{CaO} \cdot \mathrm{Al}_{2} \mathrm{O}_{3} \cdot \mathrm{CaSO}_{4} \cdot 12 \mathrm{H}_{2} \mathrm{O} \\
& +2 \mathrm{Ca}(\mathrm{OH})_{2}+2 \mathrm{H}_{2} \mathrm{O} \\
& \rightarrow 3 \mathrm{CaO} \cdot \mathrm{Al}_{2} \mathrm{O}_{3} \cdot 3 \mathrm{CaSO}_{4} \cdot 32 \mathrm{H}_{2} \mathrm{O}+2 \mathrm{NaO}, \\
& 3 \mathrm{Na}_{2} \mathrm{SO}_{4}+2\left(4 \mathrm{CaO} \cdot \mathrm{Al}_{2} \mathrm{O}_{3} \cdot 19 \mathrm{H}_{2} \mathrm{O}\right)+14 \mathrm{H}_{2} \mathrm{O} \\
& \rightarrow 3 \mathrm{CaO} \cdot \mathrm{Al}_{2} \mathrm{O}_{3} \cdot 3 \mathrm{CaSO}_{4} \cdot 32 \mathrm{H}_{2} \mathrm{O} \\
& +2\left[\mathrm{Al}(\mathrm{OH})_{3}\right] 6 \mathrm{NaOH} \text {. }
\end{aligned}
$$

The initial manifestation of the interaction between Portland cement and sodium sulfate solution, as with calcium sulfate, is an increase in resistance in the region affected by the filling of the pores of the cement paste with ettringite. With the continuous process of formation of Ettringite there will be a great tendency to cracking (SKALNY; MARCHAND; ODLER, 2003).

The strength of Portland cement can vary depending on its composition. The strength of concrete generally increases when the concentrations of aluminum oxide $\left(\mathrm{Al}_{2} \mathrm{O}_{3}\right)$ in the clinker are lower. 
This is due to the fact that lesser amount of monosulfate will be formed from cement hydration reactions, reducing the formation of ettringite (SKALNY; MARCHAND; ODLER, 2003).

\section{Magnesium sulfate attack mechanism}

Magnesium sulfate $\left(\mathrm{MgSO}_{4}\right)$ is the one that causes the most harmful effects to cement paste, being considered the most complex of the types of sulfates because it can react with all cement hydration products. $\mathrm{MgSO}_{4}$ reacts not only with $\mathrm{CH}$ but also leads to the decomposition of the $\mathrm{C}-\mathrm{S}-\mathrm{H}$ phase of the cement paste, forming expansive compounds, leading to the precipitation of brucite, $\mathrm{Mg}(\mathrm{OH})_{2}$, and the formation of the system of hydrated magnesium silicate, M-S-H (LIU et al., 2013).

When in solution, magnesium sulfate can act in two different types of chemical reactions. In both reactions, magnesium sulfate acts in an ion exchange reaction with $\mathrm{Ca}^{2+}$ ions, in two possible ways, as indicated in equations (5) and (6). In both there is formation of ettringite and brucite, which precipitate (PIASTA; MARCZEWSKA; JAWORSKA, 2014):

$$
\begin{gathered}
(\mathrm{CaO})_{3} \mathrm{Al}_{2} \mathrm{O}_{3} \cdot \mathrm{CaSO}_{4} \cdot 12 \mathrm{H}_{2} \mathrm{O}+2 \mathrm{MgSO}_{4}+2 \mathrm{Ca}(\mathrm{OH})_{2} \\
+2 \mathrm{H}_{2} \mathrm{O} \rightarrow(\mathrm{CaO})_{3} \mathrm{Al}_{2} \mathrm{O}_{3} \cdot 3 \mathrm{CaSO}_{4} \cdot 32 \mathrm{H}_{2} \mathrm{O} \\
+2 \mathrm{Mg}(\mathrm{OH})_{2} \downarrow
\end{gathered}
$$

$(\mathrm{CaO})_{3} \mathrm{Al}_{2} \mathrm{O}_{3} \cdot \mathrm{Ca}(\mathrm{OH}) \cdot 12 \mathrm{H}_{2} \mathrm{O}+3 \mathrm{MgSO}_{4}+2 \mathrm{Ca}(\mathrm{OH})_{2}$

$$
\begin{gathered}
+2 \mathrm{H}_{2} \mathrm{O} \rightarrow(\mathrm{CaO})_{3} \mathrm{Al}_{2} \mathrm{O}_{3} \cdot 3 \mathrm{CaSO}_{4} \cdot 32 \mathrm{H}_{2} \mathrm{O} \\
+3 \mathrm{Mg}(\mathrm{OH})_{2} \downarrow .
\end{gathered}
$$

Due to the low solubility of $\mathrm{Mg}(\mathrm{OH})_{2}$, when compared with $\mathrm{Mg}(\mathrm{SO})_{4}$, it precipitates in all reactions of magnesium sulfate with calcium hydroxide or any other phase of the cement paste that contains calcium. First, the $\mathrm{Mg}(\mathrm{OH})_{2}$ gel is formed and, later, brucite is formed on the surface of concrete structures or in larger pores. The more compacted layer of brucite can delay and prevent the advance of the external attack, at first. However, the $\mathrm{pH}$ of the solution tends to decrease with the release of $M g^{2_{+}}$ ions and the acidity of the solution tends to accelerate the dissociation of calcium ions from the phases present in the cement paste, promoting an increase in gypsum formation. With this, there is a depletion of $\mathrm{CH}$ in the medium and the descaling of the $\mathrm{C}-\mathrm{S}-\mathrm{H}$ begins to occur, which is converted into $\mathrm{M}-\mathrm{S}-\mathrm{H}$, which does not have any type of binding properties with the other phases of the concrete (PIASTA; MARCZEWSKA; JAWORSKA, 2014).
The degradation of $\mathrm{C}-\mathrm{S}-\mathrm{H}$ occurs gradually, a process in which $\mathrm{C}-\mathrm{S}-\mathrm{H}$ is transformed into hydrated silica $\left(\mathrm{SIO}_{2, a q}\right)$ or $\mathrm{M}-\mathrm{S}-\mathrm{H}$, or both. These reactions lead to the formation of more hydrated gypsum, brucite and magnesium silicate, as indicated in equations (7) and (8) (SKALNY; MARCHAND; ODLER, 2003):

$$
\begin{gathered}
x \mathrm{Mg}^{2+}+x \mathrm{SO}_{4}^{2-}+x \mathrm{CaO} \cdot \mathrm{SiO}_{2} \cdot a q+3 x \mathrm{H}_{2} \mathrm{O} \\
\rightarrow x \mathrm{CaSO}_{4} \cdot 2 \mathrm{H}_{2} \mathrm{O}+x \mathrm{Mg}(\mathrm{OH})_{2}+\mathrm{SiO}_{2} \cdot a q \\
2 x \mathrm{Mg}^{2+}+2 x \mathrm{SO}_{4}^{2-}+2\left[x \mathrm{CaO} \cdot \mathrm{SiO}_{2} \cdot a q\right]+y \mathrm{H}_{2} \mathrm{O} \\
\rightarrow 3 \mathrm{MgO} \cdot 2 \mathrm{SiO}_{2} \cdot 2 \mathrm{H}_{2} \mathrm{O}+2 x\left[\mathrm{CaSO}_{4} \cdot 2 \mathrm{H}_{2} \mathrm{O}\right]+ \\
+(2 x-3) \mathrm{Mg}(\mathrm{OH})_{2} .
\end{gathered}
$$

The consequence of these reactions is partially corroded concrete in which the Calcium/Silicon ratio of the remaining portions of $\mathrm{C}-\mathrm{S}-\mathrm{H}$ is not constant, being higher inside the concrete, because it has more $\mathrm{C}-\mathrm{S}-\mathrm{H}$, decreasing as approaches the surface and reaching zero in places where there was complete corrosion (SKALNY; MARCHAND; ODLER, 2003).

The influence of cement composition on attack by sulfates

The main cement compounds are tricalcium silicate $\left(C_{3} S\right)$, dicalcium silicate $\left(C_{2} S\right)$, tricalcium aluminate $\left(C_{3} A\right)$ and tetracalcium ferroalumiate $\left(C_{4} A F\right)$, and to a lesser extent, free oxides such as calcium $(\mathrm{CaO})$ and magnesium $(\mathrm{MgO})$ and gypsum $\left(\mathrm{CaSO}_{4} \cdot \mathrm{H}_{2} \mathrm{O}\right)$ (CEFIS; COMI, 2017; SKALNY; MARCHAND; ODLER, 2003). After hydration, these compounds form hydrated calcium silicate, $\mathrm{C}-\mathrm{S}-\mathrm{H}$, which is responsible for the mechanical strength of cement and ettringite.

According to Al-Amoudi (2002) and Lee and Lee (2007), the type of cement influences the attack by sulfates, and high levels of $C_{3} A$ and calcium hydroxide make cements susceptible to attack by sulfates. As well as cements with high levels of limestone addition, it has shown low resistance to attack by magnesium sulfate, in particular with thaumasite formation (GAO et al., 2008; IRASSAR, 2009).

Cements with low $C_{3} A$ contents tend to have a higher $C_{3} S / C_{2} S$ ratio and high $C_{3} S$ contents can influence the production of larger amounts of $\mathrm{CH}$ during hydration, which can directly combine with sulfate ions leading to the formation of gypsum, promoting the deterioration of hardened phases containing Portland cement (AL-AMOUDI, 2002). 
Hydration of $C_{3} S$ produces about 2.2 times more $\mathrm{CH}$ than hydration of $C_{2} S$, with $C_{3} S$ producing approximately $61 \%$ of C-S-H and $39 \%$ of $\mathrm{CH}$ and $C_{2} S$ producing $82 \%$ of $\mathrm{C}-\mathrm{S}-\mathrm{H}$ and $18 \% \mathrm{CH}$, with $\mathrm{CH}$ being responsible for the formation of gypsum in cement paste (AL-SALAMI; SALEM, 2010; LEE; LEE, 2007).

Menna Junior et al. (2020) evaluated the chemical composition of different types of cement showing that there are differences between them, so that these cements must have different resistance to attack by sulfates.

Chen, Liu and Yu (2020) showed that tests in an artificially simulated environment can be used to analyze the real deterioration of concrete under sulfate attack.

Considering the above, the present work aims to analyze the influence of the type of cement used on the resistance to attack by sulfates, having been chosen three types of cement, one of them being the most found in construction materials stores in the Curitiba region, one recommended for environments subject to attack by sulfates and the third type is a cement widely used in concrete companies.

\section{Materials and methods}

\section{Materials}

\section{Cements}

CP II F-32, CP IV-32 and CP V-ARI cements were used. The cements were removed from a single batch and stored in sufficient quantity to make all the specimens. Table 1 shows the results of the chemical analysis of the cements used.

Table 1 - Chemical composition of the cements used.

\begin{tabular}{cccc}
\hline Oxide & CP II F-32 & CP IV-32 & CP V-ARI \\
\hline $\mathrm{CaO}$ & $61.35 \%$ & $45.12 \%$ & $61.86 \%$ \\
$\mathrm{SiO}_{2}$ & $18.30 \%$ & $29.81 \%$ & $19.28 \%$ \\
$\mathrm{Al}_{2} \mathrm{O}_{3}$ & $4.28 \%$ & $9.39 \%$ & $4.46 \%$ \\
$\mathrm{Fe}_{2} \mathrm{O}_{3}$ & $2.94 \%$ & $4.17 \%$ & $3.00 \%$ \\
$\mathrm{SO}_{3}$ & $2.59 \%$ & $2.16 \%$ & $2.95 \%$ \\
$\mathrm{MgO}$ & $2.49 \%$ & $1.88 \%$ & $2.59 \%$ \\
\hline
\end{tabular}

Source: The authors.

\section{Fine Aggregate}

The fine aggregate used was a mixture of fine and medium sands in the proportion 1:1. The fineness modules for fine and medium sand were, respectively, 1.29 and 2.47, according NBR NM 248 (ABNT, 2003).
The effective diameter $(\mathrm{def}=\mathrm{d} 10$, accumulated retained percentage $=10 \%$ ) for fine sand was 0.23 and for medium sand it was 0.18 . The non-uniformity coefficient (CNU) was also calculated, which corresponds to the ratio between d60 and def, being 3.91 for fine sand and 1.56 for medium sand. CNU values less than 5 characterize materials with very uniform particles. Finally, the coefficients of curvature of the sands were calculated, a characteristic that allows to detect discontinuities in the set. Both sands were classified as well graded, with curvature coefficients less than 3 . The particle size curve of the sands is shown in Figure 1.

Figure 1 - Particle size curves of the sands

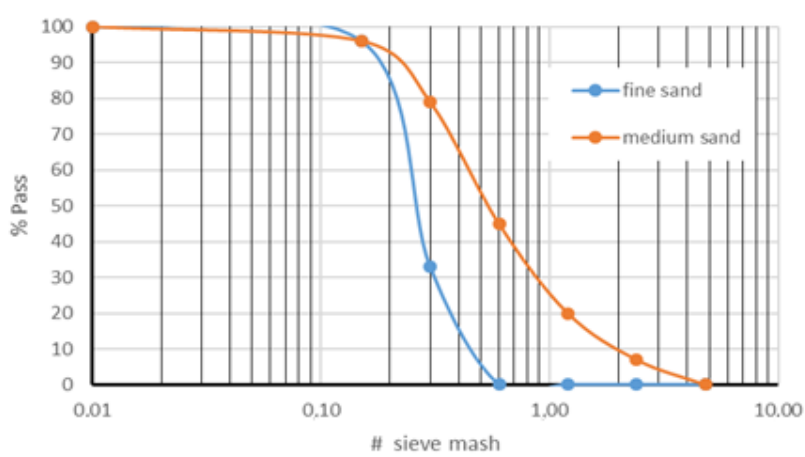

Source: The authors.

\section{Sulphates}

The calcium, sodium and magnesium sulfates used in the composition of the attack solutions were purchased from a chemical store and were from well-known trademarks. All chemicals used were "for analysis" (PA) purity, used for the designation of reagents of high purity and reliability.

\section{Methods}

\section{Preparation of the specimens}

It were made 72 specimens of $5 \times 10 \mathrm{~cm}$ composed of the three different types of Portland cement, with 24 specimens for each type, 6 used as reference and 18 for attacks, of these 6 for each type of sulfate.

Mortars were prepared in a mortar mixer, with a 1: 3 proportion with a water-cement ratio $(\mathrm{w} / \mathrm{c})$ of 0.50 , being similar to that specified for testing the compressive strength of cement, according to NBR 7215 (ABNT, 1996).

Preparation of sulfate solutions and curing of specimens

The sodium, calcium and magnesium sulfate solutions were prepared at a concentration of $10 \%$ by mass. 
For this, $500 \mathrm{~g}$ of salt and $5000 \mathrm{~g}$ of water were weighed for solubilization. This concentration was chosen in order to accelerate and intensify the sulfate attack process.

The specimens, after 28 days of curing in a humid chamber, were placed inside the solutions, where they remained for a period of 120 days. The reference specimens were cured in the same way as the others; however, were kept in water.

\section{Compressive strength test}

The tests for resistance to axial compression were performed according to NBR 7215 (ABNT, 1996). At the test date, the specimens were 153 days old. This test age was determined because it is as long as possible for the specimens to remain in an aggressive environment without prejudice to work schedule. For the test, was used universal test equipment with a load capacity of $300 \mathrm{kN}$.

Scanning electron microscopy (SEM) and energy dispersive spectroscopy (EDS)

The EDS equipment is coupled to the SEM, allowing the identification of chemical elements present in specific points selected in the sample images, during the scanning process. Energy-dispersive X-ray spectroscopy (EDS) is an analytical technique that enables the chemical characterization/elemental analysis of materials. A sample excited by an energy source (such as the electron beam of an electron microscope) dissipates some absorbed energy by ejecting a core-shell electron. A higher energy outershell electron then proceeds to fill its place, releasing the difference in energy as an X-ray that has a characteristic spectrum based on its atom of origin. This allows for the compositional analysis of a given sample volume that has been excited by the energy source. The position of the peaks in the spectrum identifies the element, whereas the intensity of the signal corresponds to the concentration of the element.

The electron microscope used to perform the SEM was the EVO MA15, from the German company Zeiss and the energy dispersion spectrometer used was from Oxford Instruments, model X - MAX $20 \mathrm{~mm}^{2}$, can be seen in Figure 2. This equipment allow the determination of the composition of observed crystalline structures.

\section{Sulfate determination test}

It was chosen for the test used in structures already built, through the adaptation of ALPHA Method 4500 $\mathrm{SO}_{4}^{2-}$ : Standard Methods for the Examination of Water and Wastewater. ASTM C 114 - 07: "Standard Methods
Figure 2 - SEM and EDS equipment.

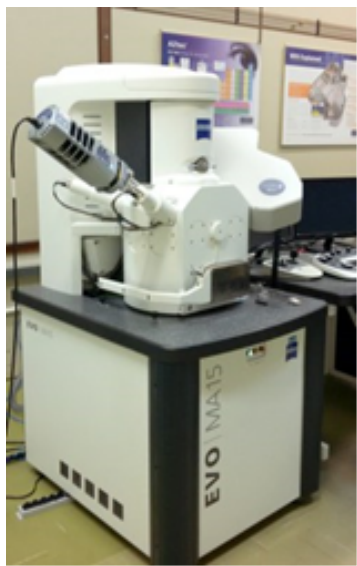

Source: The authors.

for Chemical Analysis of Hydraulic Cement" (ASTM, 2007) was created to determine the content of sulfates in cement, however it presents practically the same methodological procedure as the ALPHA Method $4500-\mathrm{SO}_{4}^{2-}$. The difference between them is how to calculate the final sulfate content, which in the first methodology, is made through the direct relationship between the ions $\mathrm{SO}_{4}^{2-}$ and $\mathrm{BaSO}_{4}$ and in ASTM C 114 - 07 it is made first by determining $\mathrm{SO}_{3}$ - in relation to BaSO4.

\section{Statistical analysis}

An analysis of variance (ANOVA) was performed to verify whether there is a statistical difference between the compressive strength results and the comparison of means by the Tukey method to verify which values are statistically equal or different.

\section{Results and discussions}

\section{Compressive strength test}

Because these reactions of concrete with sulfates directly influence the strength, one of the tests carried out to study the behavior of cements against different types of attack by sulfates was that of resistance to axial compression, whose results, averages of 6 specimens, can be seen in Table 2.

The results of axial compression strength of the specimens submitted to the attack of sodium and calcium sulfate showed an increase due to the formation of etringite in the pores, as verified by Skalny, Marchand and Odler (2003), and considering that the test period was short, the components did not crack. However, Chen, Liu and Yu (2020) found that with increasing age, there is a decrease in strength. 
Table 2 - Chemical composition of the cements used.

\begin{tabular}{ccccc}
\hline Sample & Reference & $\mathrm{Na}_{2} \mathrm{SO}_{4}$ & $\mathrm{CaSO}_{4}$ & $\mathrm{MgSO}_{4}$ \\
\hline $\mathrm{CP} \mathrm{II} \mathrm{F}-32 *^{*}$ & $12.7_{a}$ & $15.4_{a, b}$ & 13.9 & $12.4_{b}$ \\
CP IV-32* $^{*}$ & $17.3_{c}$ & $19.2_{d}$ & $13.7_{c, d}$ & $14.9_{d}$ \\
CP V-ARI* $^{*}$ & 15.0 & 17.3 & 18.6 & 14.8 \\
\hline
\end{tabular}

* (MPa)

Same letters indicate statistically different results.

Source: The authors.

In order to verify whether the strength averages were statistically equal, the ANOVA test of variance was used. For the CP II-F-32 cement, it was verified that only the specimens submitted to the attack by $\mathrm{Na} 2 \mathrm{SO} 4$ showed an increase of $21.26 \%$ in relation to the reference, indicated by ANOVA. For CP IV-32 cement, only the specimens submitted to the attack by $\mathrm{CaSO}_{4}$ showed statistically different results, that is, a $20.81 \%$ decrease in strength. For CP V-ARI cement, all results are considered statistically equal.

\section{Sulfates action}

The determination of the sulfate content in the mortar specimens was made according to the method used by Mazer et al. (2014), which corresponds to an adaptation of the ALPHA Method $4500-S_{4}^{2-}$ for determining the content of sulfates in structures already built. The average results of 6 samples per type of cement can be seen in Table 3 .

The sulfate content was calculated according to equation (9), as the ALPHA METHOD-4500 $\mathrm{SO}_{4}^{2-}$ suggests:

$$
S O_{4}(\%)=\left(\frac{M_{\text {calcined }} \times 0.4116}{M_{\text {initial }}}\right) \times 100 .
$$

Where the mass of barium sulfate was transformed into sulfate taking into account the molar masses of these chemical compounds. The levels of sulfates found in the reference specimens can be correlated with the sulfate added in the form of plaster during the cement manufacturing process. The final sulfate content was obtained by subtracting the values of the reference specimens from the specimens exposed to different types of sulfates. Figure 3 shows the total levels of $\mathrm{SO}_{4}$ and the levels of sulfate that effectively penetrated the specimens.

As can be seen, the three types of cement presented different degrees of performance in relation to the type of aggressive agent to which they were exposed. The specimens exposed to the attack solution by $\mathrm{CaSO}_{4}$ showed lower percentages of sulfate content. The result corrobo-
Table 3 - Results of determining the sulfate content.

\begin{tabular}{ccc}
\hline & \multicolumn{2}{c}{ content Sulfates $\left(\mathrm{SO}_{4} \%\right)$} \\
\cline { 2 - 3 } Sample & Total & Penetrating \\
\hline & Reference & - \\
$\mathrm{CP}$ V-ARI & 0.91 & - \\
$\mathrm{CP}$ IV-32 & 0.58 & - \\
$\mathrm{CP}$ II F-32 & 0.65 & 1.47 \\
\hline & $\mathrm{MgSO}_{4}$ \\
\hline $\mathrm{CP}$ V-ARI & 2.8 & 1.40 \\
$\mathrm{CP}$ IV-32 & 1.97 & 1.81 \\
$\mathrm{CP}$ II F-32 & 2.46 & \\
\hline & $\mathrm{Na}_{2} \mathrm{SO}_{4}$ & 0.98 \\
\hline $\mathrm{CP}$ V-ARI & 1.89 & 0.82 \\
$\mathrm{CP}$ IV-32 & 1.39 & 1.23 \\
$\mathrm{CP}$ II F-32 & 1.89 & \\
\hline & $\mathrm{CaSO}_{4}$ & 0.56 \\
\hline $\mathrm{CP}$ V-ARI & 1.47 & 0.41 \\
$\mathrm{CP}$ IV-32 & 0.98 & 0.50 \\
$\mathrm{CP}$ II F-32 & 1.15 & \\
\hline
\end{tabular}

Source: The authors.

Figure $3-\mathrm{SO}_{4}$ content.

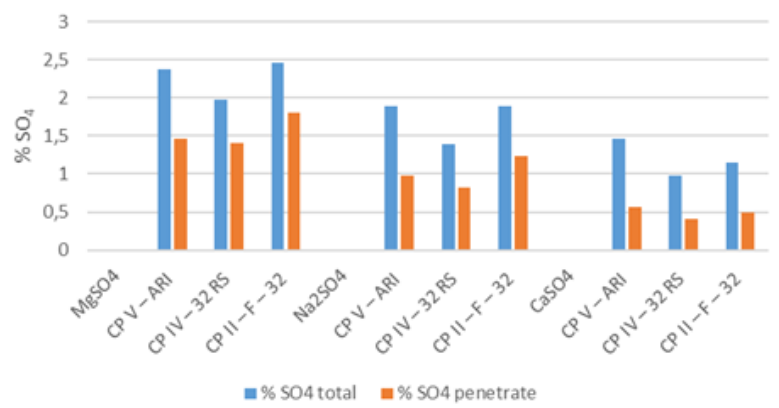

Source: The authors.

rates with the expected, since calcium sulfate is the least aggressive among the three. Among the three types of cement tested, for the same etching solution, the ones that were most attacked, therefore presenting higher final sulfate contents, where CP V-ARI cements, with $0.56 \%$ by weight and CP II F-32 cement., with $0.50 \%$ by weight. CP IV-32 cement proved to be the most resistant to attack by $\mathrm{CaSO}_{4}$, with a sulfate content of $0.41 \%$ by weight, due to the fact that in its composition there are pozzolans, which makes it resistant to attack by sulfates.

The second aggressive agent responsible for incorporating a higher content of sulfates in the samples was $\mathrm{Na}_{2} \mathrm{SO}_{4}$. The final levels reached values close to double when compared to the levels observed in the attack by $\mathrm{CaSO}_{4}$. This time, CP II F-32 cement was the most at- 
tacked, having a final sulfate content of $1.23 \%$ by mass, followed by CP V-ARI, with $0.98 \%$ by mass. Again, the most resistant cement was CP IV-32, with a sulfate content of $0.82 \%$ by weight.

The $\mathrm{MgSO}_{4}$ attack was the most aggressive for all types of cement, this is due to the attack that this type of sulfate makes on the C-S-H, which can be seen in the SEM images. The most attacked cement was CP II F-32, with a sulfate content of $1.81 \%$ by mass, followed by $\mathrm{CP}$ V-ARI cement, with $1.47 \%$ by mass. Again, as expected, CP IV-32 cement was the most resistant of the three, with $1.40 \%$ sulfate content by mass. As can be seen, the attack by magnesium sulfate was the most aggressive among the three.

As noted, CP II F-32 cement was more attacked when in contact with solutions containing $\mathrm{Na}_{2} \mathrm{SO}_{4}$ and $\mathrm{MgSO}_{4}$. CP II F-32 is cement composite with the addition of limestone filler, between 6 and 10\%, according to NBR 11578 (ABNT, 1991) and gypsum.

The use of limestone fillers in cement and concrete brings benefits such as reduced water demand, which improves the strength of the concrete, in addition to making it more economical (GAO et al., 2008; IRASSAR, 2009). Despite these benefits, the presence of high levels of limestone in cement or concrete tends to affect durability, allowing the penetration of chlorides, the appearance of carbonation reactions, reduced resistance to sulfates, among others. With regard to attack by sulfates, cements with this type of addition have been shown to be more susceptible to attack by magnesium sulfate, more specifically by the formation of thaumasite (GAO et al., 2008; IRASSAR, 2009).

The greater susceptibility of CP II F-32 cement to attack by sulfates is related to the increase in the rate of cement hydration caused by limestone filler in the early ages, which leads to the precipitation of calcium hydroxide particles around the filler particles and on the surface of the aggregates. The crystals of $\mathrm{CH}$ formed are considered a weak point or less resistant to attack by sulfates and this process is called heterogeneous nucleation (GONZÁLEZ; IRASSAR, 1998, IRASSAR, 2009).

According to AL - Amoudi (2002), the type of cement significantly influences any type of attack by sulfates in concrete structures. Among hydration products, calcium hydroxide and alumina-containing phases are more vulnerable to attack by sulfates. During the hydration process, cements with more than $5 \% C_{3} A$ are likely to have alumina almost entirely in the form of hydrated monosulfate. In the presence of $\mathrm{CH}$, when the cement paste comes into contact with the sulfate ions, a large part of the hydrated phases containing alumina will be converted into ettringite, which can generate expansive reactions in the concrete.

The intermediate sulfate content observed in the $\mathrm{CP}$ V-ARI cement might have been caused by the high $C_{3} S$ content. The increase in $C_{3} S$ content or in the $C_{3} S / C_{2} S$ proportion of the cement promotes an increase in the amount of $\mathrm{CH}$, culminating in the reduction of resistance to attack by sulfates. Hydration of $C_{3} S$ produces about 2.2 times more $\mathrm{CH}$ than hydration of $\mathrm{C}_{2} \mathrm{~S}$. Thus, the intermediate resistance to attack by sulfates verified in the tests performed is justified (AL_SALAMI; SALEM, 2006; SHANAHAN; ZAYED, 2007; PRASSAD; JAIN; AHUJA, 2006). CP IV32 cement, according to the manufacturer's specifications, can present between 15 and $50 \%$ of addition of pozzolans in its constitution, in addition to having low hydration heat, which makes it resistant to sulfates (AL-AMOUDI, 2002). Pozzolans react with the calcium hydroxide formed during the hydration of Portland cement. There is, therefore, a reduction in $\mathrm{CH}$ levels and formation of higher amounts of secondary C-S-H (AHMAD; NOOR, 2009; BHATTY; TAYLOR, 2006). Analysis by SEM and EDS The confirmation of the formation of expansive compounds was made through SEM, with the objective of carrying out the morphological analysis of the structures formed and/or modified due to the attack. The confirmation of the elemental chemical composition of these structures was done through the EDS test.

In Figure 4, it is possible to observe the SEM images of the CP II F-32 cement, illustrating the reference samples (a), submitted to the attack of calcium sulfate (b), sodium sulfate (c) and magnesium sulfate (d), 153 days old.

In Figure 4(a), it is possible to identify a very intertwined structure of ettringite, a fact confirmed by the presence of the elements $\mathrm{Ca}, \mathrm{S}$ and $\mathrm{Al}$ in the EDS (1). In (2), a small hexagonal plate suggestive of portlandite is observed, confirmed by the high $\mathrm{Ca}$ content obtained by the EDS analysis.

Through Figure 4(b), it is possible to identify a series of grouped acicular structures that suggest being ettringite due to the elementary composition provided by the EDS, with the majority presence of the elements $\mathrm{Ca}, \mathrm{S}, \mathrm{Si}$ and $\mathrm{Al}$ (3). However, morphologically these structures have a different shape from the usual structures of ettringite, this may have been caused by the attack of calcium sulfate. In (4), it is possible to observe the formation of a structure suggestive of $\mathrm{C}-\mathrm{S}-\mathrm{H}$, confirmed in the DES by the high concentration of $\mathrm{Si}$, in agreement with the results obtained by Tashima et al. (2012) and Campos and Paulon (2015). 
Figure 4 - SEM images of CP II F-32 cement: (a) reference samples; (b) submitted to the attack of calcium sulfate; (c) sodium sulfate and (d) and magnesium sulfate.

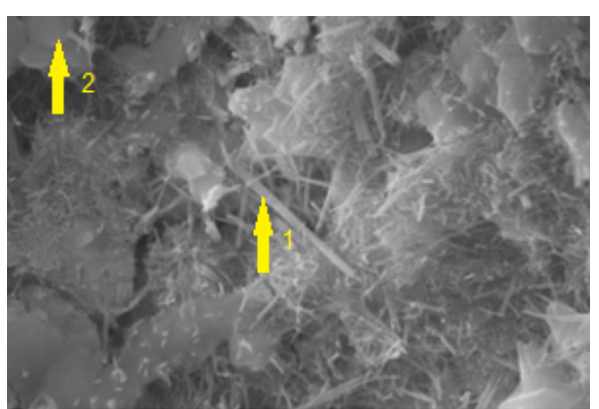

(a)

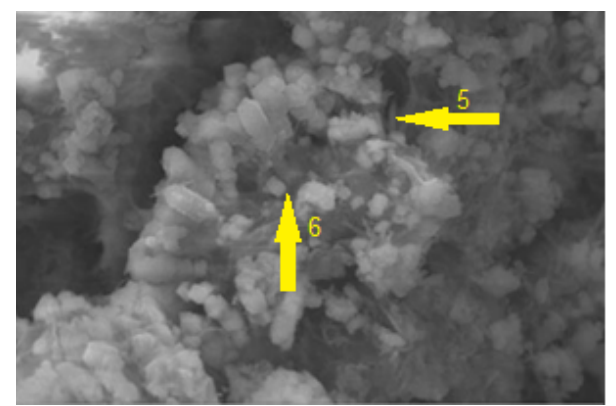

(c)

Source: The authors.

In the micrograph shown in Figure 4(c), it is possible to observe the formation of small acyclic crystals suggestive of ettringite (5) and the other structures in the shape of hexagonal crystals suggest the presence of portlandite (6). In the EDS composition of 5 , the presence of $\mathrm{Ca}, \mathrm{S}$ and $\mathrm{Al}$ is verified, confirming the formation of ettringite and in 6 , it is predominantly $\mathrm{Ca}$. When comparing Figure 4(c) with Figure 4(a), the lesser amount of ettringite, suggesting, therefore, attack by sulfates in an early stage. According to to González and Irassar (1998) and Irassar (2009), this is due to the fact that CP II F-32 cement, during its hydration process, leads to precipitation and accumulation of calcium hydroxide particles, serving as a focus for the start of the sulfate attack.

The micrograph shown in Figure 4(d) shows the formation of small acyclic crystals suggestive of ettringite (7). In the EDS composition of (7), $\mathrm{Ca}, \mathrm{S}$ and $\mathrm{Al}$ are present, confirming the formation of ettringite. In (8), it is possible to observe the formation of a structure suggestive of $\mathrm{C}-\mathrm{S}-\mathrm{H}$, confirmed in EDS by the high concentration of Si. In (9), it is suggested that it is one of several portlandite plates present in the micrograph. When comparing Figure 4(d) with Figure 4(a), it is possible to observe the formation of ettringite and portlandite in a more interlaced manner, giving an indication of the onset of the attack by sulfates.

Comparing Figure 4(d) with Figure 4(b) and Figure 4(c), it is possible to notice clear differences in the morphological structures formed and/or altered. The attack

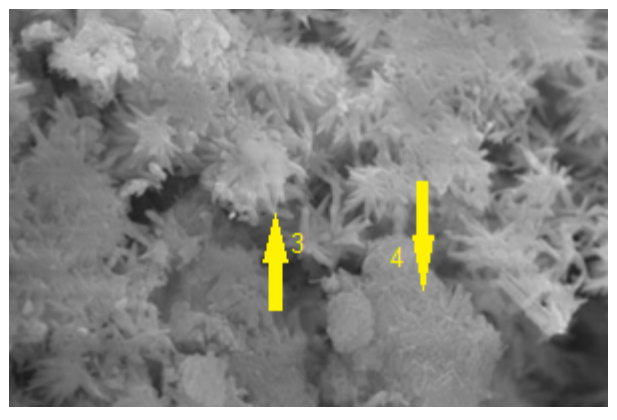

(b)

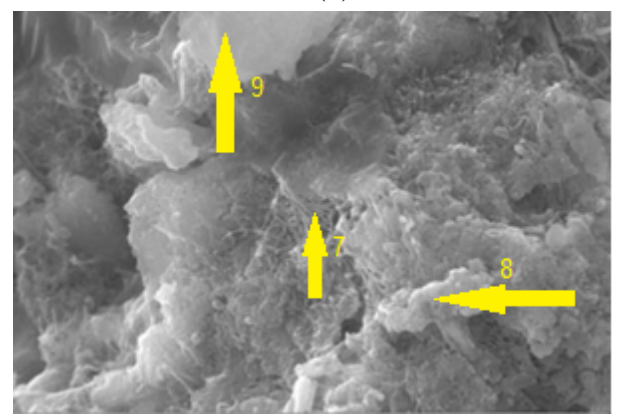

(d)

by magnesium sulfate showed more altered phases in the cement paste, proving to be the most aggressive agent.

The microscopy images of the CP IV-32 cement are shown in Figure 5, showing the reference samples (a), submitted to the attack of calcium sulfate (b), sodium sulfate (c) and magnesium sulfate (d), at 153 days of age.

In the micrograph illustrated in Figure 5(a), it is possible to identify formations suggestive of $\mathrm{C}-\mathrm{S}-\mathrm{H}$ in (1) and portlandite in (2), a fact confirmed by the presence of the elements $\mathrm{Ca}$ and $\mathrm{Si}$, according to the DES test. There was no formation of ettringite in the sample of this cement. The predominance of structures suggestive of $\mathrm{C}-\mathrm{S}-\mathrm{H}$ and the small number of structures corresponding to portlandite were expected for this cement, due to the addition of pozzolans that consume portlandite for the formation of $\mathrm{C}-\mathrm{S}-\mathrm{H}$.

Through Figure 5(b), it is possible to observe the formation of ettringite (3), confirmed by the concentrations of $\mathrm{S}$ and $\mathrm{Al}$ found in the EDS. Formations suggestive of $\mathrm{C}-\mathrm{S}-\mathrm{H}$ (4) were also identified, due to the presence of the elements $\mathrm{Ca}$ and $\mathrm{Si}$. Comparing Figure 5(a) with 5(b), it can be seen that there was an attack by calcium sulfate, because calcium sulfate reacts with hydrated calcium aluminate to form ettringite, as described by Piasta, Marczewska and Jaworska (2014).

In the micrograph shown in Figure 5(c), it was not possible to observe the presence of ettringite in this sample because there was no concentration of sulfur (S) that con- 
Figure 5 - SEM images of CP IV-32 cement: (a) reference samples; (b) submitted to the attack of calcium sulfate; (c) sodium sulfate and (d) and magnesium sulfate.

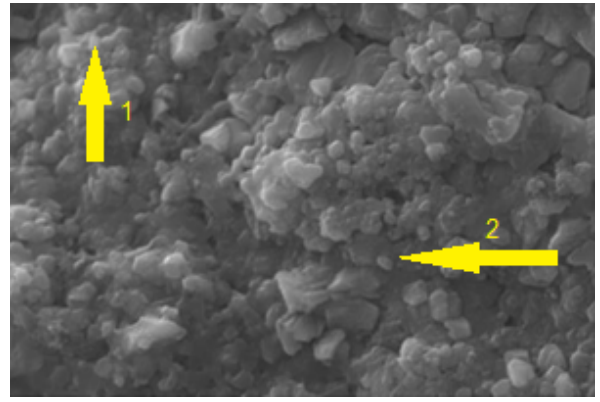

(a)

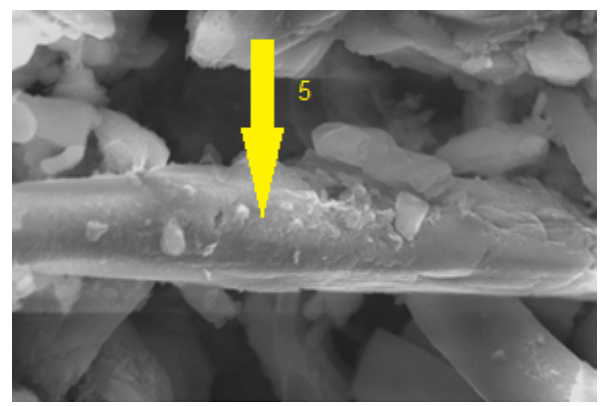

(c)

Source: The authors

firmed the presence of the structure. It is suggested for this sample only the presence of hexagonal plates and formations suggestive of the presence of portlandite. The EDS confirmed this with a predominance of the Ca concentration of the analyzed structures. It is possible to observe that sodium sulfate was the least aggressive solution for CP IV-32 cement. It is not possible to confirm the attack by sulfates using this micrograph.

The micrograph shown in Figure 5(d) shows the extensive formation of small agglomerated plaques suggestive of monosulfate (6). The EDS composition for structure 1 contains $\mathrm{Ca}, \mathrm{S}$ and $\mathrm{Al}$, confirming the monosulfate composition. The other structures presented in the form of acicles (7) and the more elongated filaments (8) do not present the element $\mathrm{Al}$ in the EDS, excluding the possibility of being ettringite and/or monosulfate. The structures indicated as (7) and (8) are mainly composed of $\mathrm{Mg}$ and Si in very similar proportions, indicating the possible replacement of $\mathrm{Ca}$ by $\mathrm{Mg}$ and conversion of $\mathrm{C}-\mathrm{S}-\mathrm{H}$ to $\mathrm{M}-\mathrm{S}-\mathrm{H}$. The presence of $\mathrm{M}-\mathrm{S}-\mathrm{H}$ demonstrates that there was a decalcification of $\mathrm{C}-\mathrm{S}-\mathrm{H}$, altering the cement structure, indicating an advanced state of attack (AMIN et al., 2008; BROWN; BADGER, 2000; GAO et al., 2008).

Comparing Figure 5(d) with Figure 5(a), Figure 5(b) and Figure 5(c), it can be seen that attack by magnesium sulfate was the most aggressive. The microscopy images of the CP V-ARI cement are shown in Figure 6, showing the reference samples (a), submitted to the attack of

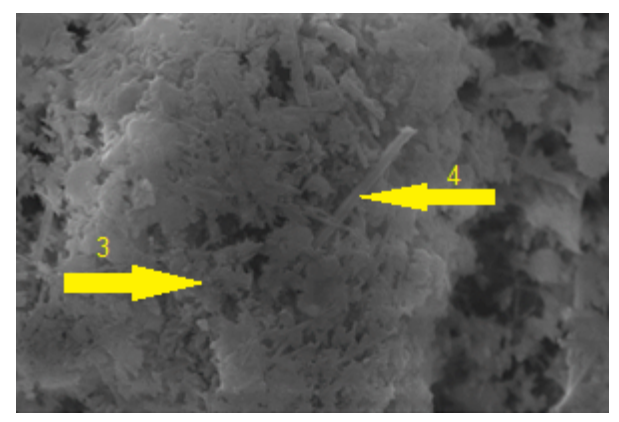

(b)

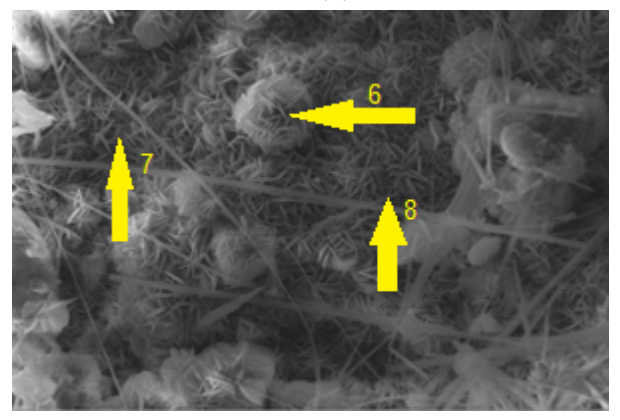

(d)

calcium sulfate (b), sodium sulfate (c) and magnesium sulfate (d), at 153 days of age.

In the micrograph of Figure 6(a), it is possible to identify some structures corresponding to etringite, a fact confirmed by the presence of the elements $\mathrm{Ca}, \mathrm{S}$ and $\mathrm{Al}$ in the EDS.

The micrograph shown in Figure 6(b) corresponds to a sample made with CP V-ARI cement, submitted to the attack of calcium sulfate, at 153 days of age. In this figure, it is possible to observe structures in a hexagonal format compatible with portlandite crystals (1), confirmed by EDS for containing a high concentration of Ca. In (2) it is possible to observe a structure with conformation indicative of $\mathrm{C}-\mathrm{S}-\mathrm{H}$, with elementary composition formed basically by $\mathrm{Ca}$ and $\mathrm{Si}$. There are also some acicular crystals suggestive of etringite (3), which can be confirmed by the result of the analysis by DES providing $\mathrm{Ca}, \mathrm{S}$ and $\mathrm{Al}$ as an elemental composition (CAMPOS; PAULON, 2015, TASHIMA et al., 2012).

The comparison of Figure 6(b) with Figure 6(a) does not allow us to prove that the calcium sulfate caused the attack by sulfates in the specimens molded with CP V-ARI cement, given the smaller amount of structures suggestive of ettringite observed in Figure 6(a).

The micrograph shown in Figure 6(c) corresponds to a sample made with CP V-ARI cement, submitted to the attack of sodium sulfate, at 153 days of age. In this figure, it is possible to observe the presence of a few 
Figure 6 - SEM images of CP V-ARI cement: (a) reference samples; (b) submitted to the attack of calcium sulfate; (c) sodium sulfate and (d) and magnesium sulfate.

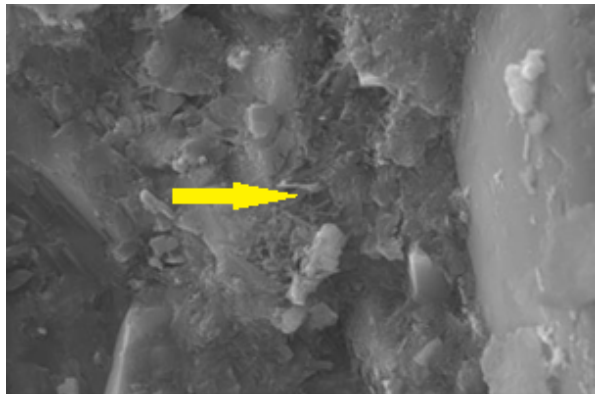

(a)

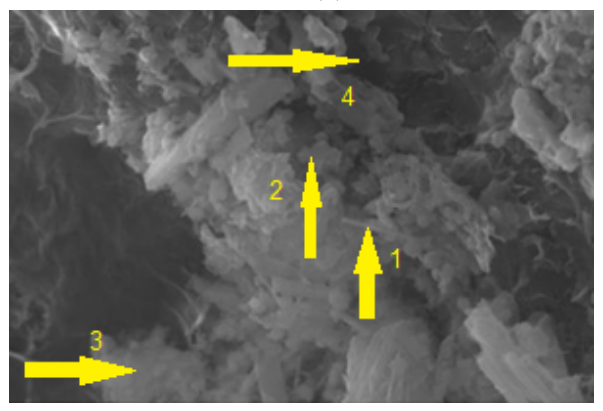

(c)

Source: The authors.

crystals in acicular format suggestive of etringite, with an elemental composition of $\mathrm{Ca}, \mathrm{S}$ and $\mathrm{Al}$, confirmed by EDS (1). It is also possible to observe the presence of structures compatible with portlandite (2) and C-S-H (3), containing predominant concentrations of $\mathrm{Ca}(1)$ and $\mathrm{Ca}$ and $\mathrm{Si}$ (2). There is also a fissure (4).

Comparing Figure 6(c) with Figure 6(a) and Figure $6(\mathrm{~b})$, it is not possible to prove the attack by sodium sulfate in CP V-ARI cement.

The micrograph shown in Figure 6(d) corresponds to a sample made with CP V-ARI cement, submitted to the attack of magnesium sulfate, at 160 days of age. Through Figure 5(d) (1) it is possible to observe the formation of small agglomerated plaques and in the EDS are mainly composed of $\mathrm{Mg}$ and $\mathrm{Si}$, indicating the replacement of $\mathrm{Ca}$ by $\mathrm{Mg}$ and conversion of $\mathrm{C}-\mathrm{S}-\mathrm{H}$ into $\mathrm{M}-\mathrm{S}-\mathrm{H}$. The presence of $\mathrm{M}-\mathrm{S}-\mathrm{H}$ demonstrates that there was a decalcification of $\mathrm{C}-\mathrm{S}-\mathrm{H}$ altering the cement structure, indicating an advanced state of attack, confirming the type of structure (AMIN et al., 2008; BROWN; BADGER, 2000; GAO et al., 2008).

By comparing Figure 6(d) with Figure 6(a), Figure 6(b) and Figure 6(c), it can be seen that magnesium sulfate attack was the most aggressive.

The results presented show the importance of choosing the cement to be used in environments subject to the action of sulfates, with CP IV-32 showing the least deterioration and the lowest concentration of sulfates in all

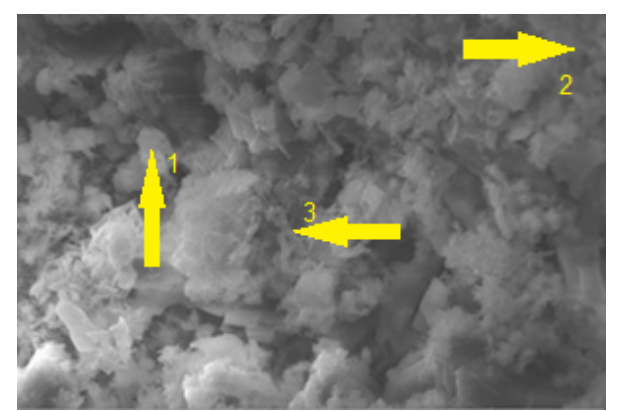

(b)

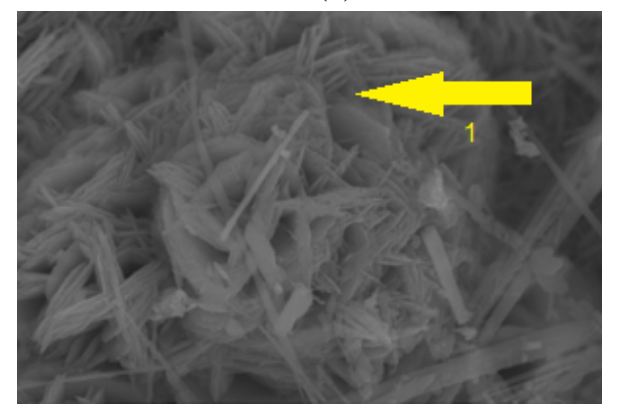

(d)

analyzes carried out, indicating its greater resistance to attack of sulfates. This corroborates with Chen, Liu and $\mathrm{Yu}$ (2020) who observed changes in the microstructure, compositions and microstructure of concrete due to the formation of expansive products and decomposition of hydration products, which are different for different types of cement.

\section{Conclusions}

The experimental data on compressive strength revealed unsatisfactory results to establish a correlation between the type of cement and the resistance to attack by sulfates. These results may have occurred due to the short time of contact of the specimens with the attack solution.

The sulfate content determined in the laboratory revealed that there was penetration of sulfates in all specimens. The CP II F-32 cement sample showed the highest levels of magnesium and sodium sulfates, with the highest concentration in the sample that was in contact with magnesium sulfate, due to the addition of limestone filler that favors increased heat of hydration at early ages. The CP IV32 cement had the lowest concentrations, a result expected for containing pozzolan in its composition and being a sulfate resistant cement. CP V-ARI cement presented intermediate levels of sulfates, except for calcium sulfate. The sulfate contents in this cement may have been caused by the high $C_{3} S$ content that promotes the quantitative 
increase in $\mathrm{CH}$, therefore, the type of cement influenced quantitatively in the penetration by sulfates.

When performing the micrograph analysis, it was observed that the greatest microstructural changes occurred for all cements that were in contact with the magnesium sulfate solution, corroborating the quantification performed for the sulfate contents, where the magnesium sulfate acted aggressive in cement mortars CP II F-32 and CP V-ARI. For CP II F-32, sodium sulfate showed the least formation of etringite, suggesting that it was the least aggressive compound for this type of cement, which did not occur for CP IV-32 cement, where this solution gave the specimens major changes in the microstructure.

\section{Acknowledgments}

We thank Multi-User Center for Materials Characterization - CMCM of UTFPR-CT for carrying out the SEM and DES tests.

\section{References}

ABNT - ASSOCIAÇÃO BRASILEIRA DE NORMAS TÉCNICAS. NBR 11578: cimento Portland composto. Rio de Janeiro: ABNT, 1991. p. 1 - 5.

ABNT - ASSOCIAÇÃO BRASILEIRA DE NORMAS TÉCNICAS. NBR 7215: cimento Portland - determinação da resistência à compressão. Rio de Janeiro: ABNT, 1996. p. $1-8$.

ABNT - ASSOCIAÇÃO BRASILEIRA DE NORMAS TÉCNICAS. NBR NM 248: agregados - determinação da composição granulométrica. Rio de Janeiro: ABNT, 2003. p. $1-6$.

AHMAD, M. H.; NOOR, N. M. Chemical attack of Malaysian pozzolans concrete. Journal of Science and Technology, London, v. 1, p. 11 - 24, 2009.

AL-AMOUDI, O. S. B. Attack on plain and blended cements exposed to aggressive sulfate environments. Cement \& Concrete Composites. 24, 305 - 316, 2002.

AL-SALAMI, A. E.; SALEM, A. Effects of mix composition on the sulfate resistance of blended cements. International Journal of Civil \& Environmental Engineering, [Ghaziabad], v. 10, n. 6, p. 37 - 41, 2010.

AMIN, M. M.; JAMALUDIN, S. B.; PA, F. C.; CHUEN, K. K. Effects of magnesium sulfate attack on ordinary Portland cement (OPC) mortars. Portugaliae Electrochimica Acta, Aveiro, v. 26, p. 235 - 242, 2008.
ASTM - AMERICAN SOCIETY FOR TESTING AND MATERIALS. Standard test methods for chemical analysis of hydraulic cement. West Conshohocken: ASTM International, 2007. DOI 10.1520/C0114-07.

BHATTY, J. I.; TAYLOR, P. C. Sulfate resistance of concrete using blended cements or supplementary cementitious materials. [S. l.]: Portland Cement Association, 2006. p. 1 - 21. (R\&D Serial, n. 2916a).

BROWN, P. W.; BADGER, S. The distributions of bound sulfates and chlorides in concrete subjected to mixed $\mathrm{NaCl}$, $\mathrm{MgSO}_{4}, \mathrm{Na}_{2} \mathrm{SO}_{4}$ attack. Cement and Concrete Research, Elmsford, v. 30, p. 1535 - 1542, 2000.

CAMPOS, M. A.; PAULON, V. A. Utilização de agregados alternativos de isoladores elétricos de porcelana em concretos. Concreto y Cemento Investigación y Desarrollo, Ciudad del México, v. 7, n. 1, p. 30 - 43, 2015.

CEFIS, N.; COMI, C. Chemo-mechanical modelling of the external sulfate attack in concrete. Cement and Concrete Research, Oxford, v. 93, p. 57-70, 2017.

CHEN, Y.; LIU, P.; YU, Z. Study on degradation of macro performances and micro structure of concrete attacked by sulfate under artificial simulated environment. Construction and Building Materials, Guildford, v. 260, p. 119951, 2020. DOI 10.1016/j.conbuildmat.2020.119951.

HOPE FILHO, J.; SOUZA, M. H. F.; PEREIRA, E.; PORTELLA, K. F. Ataque de matrizes cimentícias por sulfato de sódio: adições minerais como agentes mitigadores. Cerâmica, São Paulo, v. 61, n. 358, p. 168-177, 2015.

GAO, X.; MA, B.; YANG, Y.; SU, A. Sulfate attack of cement-based material with limestone filler exposed to different environments. Journal of Materials Engineering and Performance, Materials Park, v. 17, p. 543 - 549, 2008.

GONZÁLEZ, M. A.; IRASSAR, E. F. Effect of limestone filler on the sulfate resistance of low $C_{3} A$ Portland cement. Cement and Concrete Research, Oxford, v. 28, n. 11, p. 1655 - 1667, 1998.

GUO, J.; LIU, P.; WU, C.; WANG, K. Effect of dry-wet cycle periods on properties of concrete under sulfate attack. Applied Sciences, Basel, v. 11, n. 888, 2021. DOI: doi.org/10.3390/app11020888. 
IRASSAR, E. F. Sulfate attack on cementitious materials containing limestone filler: a review. Cement and Concrete Research, Oxford, v. 39, p. 241 - 254, 2009.

LEE, S. T.; LEE, S. H. Sulfate attack and the role of cement compositions. Journal of the Korean Ceramic Society, Seoul, v. 44, n. 9, p. 465 - 470, 2007.

LIU, Z.; DENG, D.; SCHUTTER, G.; YU, Z. The effect of $\mathrm{MgSO}_{4}$ on thaumasite formation. Cement and Concrete Composites. Barking, v. 35, p. 102 - 108, 2013.

MAZER, W.; MACIOSKI, G.; SOTO, N.; BAETTKER, E. Determinação do teor de íons sulfato em estruturas de concreto. In: CONGRESSO BRASILEIRO DE ENGENHARIA QUÍMICA, 20., 2014, Florianópolis. Anais [... ] Florianópolis: Cobeq, 2014. p. 13574-13580.

MENNA JUNIOR, D.; BALCÃO, V. M. C. F.; CHAUD, M. V.; VILA, M. M. D. C.; ARANHA, N.; YOSHIDA, V. M. H.; OLIVEIRA JUNIOR, J. M. Physicochemical evaluation of portland cement produced in Brazil via X-ray fluorescence and mechanical strength, Semina: Ciências Exatas e Tecnológicas, Londrina, v. 41, n. 1, p. 3-12, 2020. DOI: http://dx.doi.org/10.5433/1679-0375.2020v41n1p3.

NAJIMI, M.; POURKHORSHIDI, J. S. A. R. Durability of copper slag contained concrete exposed to sulfate attack. Construction and Building Materials. Guildford, v. 25, p. $1896-1905,2011$.

PIASTA, W.; MARCZEWSKA, J.; JAWORSKA, M. Some aspects and mechanisms of sulfate attack. Structure and Environment, Kielce, v. 6, p. 19 - 24, 2014.
PRASAD, J.; JAIN, D. K.; AHUJA, A. K. Factors influencing the sulphate resistance of cement concrete and mortar. Asian Journal of Civil Engineering: Building and Housing, Switzerland, v. 7, n. 3, p. 259 - 268, 2006.

SHANAHAN, N.; ZAYED, A. Cement composition and sulfate attack Part I. Cement and Concrete Research, Elmsford, v. 37, p. 618, 2007.

SKALNY, J.; MARCHAND, J.; ODLER, I. Sulfate Attack on Croncrete. London: Spon Press, 2003.

ASHIMA, M. M.; FIORITI, C. F.; AKASAKI, J. L.; BERNABEU, J. P.; SOUSA, L. C.; MELGES, J. L. P. Cinza de casca de arroz (CCA) altamente reativa: método de produção e atividade pozolânica. Ambiente Construído, São Paulo, v. 12, n. 2, p. 151 - 163, 2012.

WANG, K.; GUO, J.; WU, H.; YANG, L. Influence of dry-wet ratio on properties and microstructure of concrete under sulfate attack. Construction and Building Materials, Guildford, v. 263, p. 120635, 2020.

ZHANG, M.; CHEN, J.; LV, Y.; WANG, D.; YE, J. Study on the expansion of concrete under attack of sulfate and sulfate-chloride. Construction and Building Materials, Guildford, v. 39, p. 26 - 32, 2013.

ZHANG, Z.; ZHOU, J.; YANG, J.; ZOU, Y.; WANG, $Z$. Understanding of the deterioration characteristic of concrete exposed to external sulfate attack: Insight into mesoscopic pore structures. Construction and Building Materials, Guildford, v. 260, p. 119932, 2020. DOI: https://doi.org/10.1016/j.conbuildmat.2020.119932. 